\title{
Optimalisasi system kelas virtual berbasis Google Classroom dan hipnoterapi
}

\author{
Imma Rachayu ${ }^{1, a)}$, Diah Selviani ${ }^{2}$ \\ ${ }^{1)}$ Program studi Pendidikan Komputer Universitas Dehasen Bengkulu \\ ${ }^{a)}$ Corresponding Author: immarachayu@gmail.com
}

\begin{abstract}
The purpose of this study was to optimize the virtual classroom system based on google classroom and hypnotherapy during the Covid-19 pandemic. The research method uses qualitative research, namely literature, interviews, the making process, implementation and evaluation. The results showed that of the 37 students there were 27 students who worked on assignments and exam questions on time based on the agreed time before the exam started with a percentage of $73 \%$. While 10 people have not been able to be on time in doing the assignments and exam questions that have been given with a percentage of $27 \%$. The cause based on the interview were network limitations. In this study it can be concluded that the optimization of the virtual class system is able to provide benefits in the use of google classrooms for lecturers and students during the Covid-19 pandemic by providing assignments, assessment schemes, active communication in discussing material, time efficiency in the learning process. In line with the learning process students are given suggestions in their subconscious mind to stay focused and concentrate on the lecture material and be able to manage their positive thought patterns and actions in accordance with the expectations of lecturers and parents.
\end{abstract}

Keywords: optimization, virtual class system, google classroom, hypnotherapy.

\begin{abstract}
ABSTRAK
Tujuan penelitian ini adalah untuk mengoptimalisasi sistem kelas virtual berbasis google classroom dan hipnoterapi pada masa pandemi covid-19. Metode penelitian menggunakan kualitatif research yaitu kepustakaan, wawancara, proses pembuatan, implementasi dan evaluasi. Hasil penelitian menunjukan bahwa dari 37 orang mahasiswa ada 27 orang mahasiswa yang mengerjakan tugas maupun soal ujian tepat waktu berdasarkan waktu yang telah disepakati bersama sebelum ujian di mulai dengan persentase $73 \%$. Sedangkan 10 orang belum mampu tepat waktu dalam mengerjakan tugas dan soal ujian yang telah diberikan dengan persentase $27 \%$. Adapun penyebabnya berdasarkan wawancara adalah keterbatasan jaringan. Penelitian ini dapat disimpulkan bahwa optimalisasi sistem virtual class mampu memberikan manfaat dalam pemanfaatan google classroom bagi dosen dan mahasiswa di masa pandemi covid-19 dengan memberikan tugas, skema penilaian, komunikasi yang aktif dalam membahas materi, efisiensi waktu dalam proses pembalajaran berlangsung. Sejalan dengan proses pembelajaran mahasiswa diberikan sugesti di dalam alam bawah sadar mereka untuk tetap fokus dan konsentarasi terhadap materi perkuliahan dan dapat memanajemen pola pikir positif dan tindakan mereka yang sesuai dengan harapan dosen dan orang tua.
\end{abstract}

Kata kunci : optimalisasi, sistem class virtual, google classroom, hypnotherapy. 


\section{Pendahuluan}

Data pengguna internet di Indonesia pada Januari 2020 ada 175,4 juta pengguna internet di Indonesia. Jumlah pengguna internet di Indonesia meningkat 25 juta $( \pm 17 \%)$ antara tahun 2019 dan 2020. Penetrasi internet di Indonesia mencapai 64\% pada Januari 2020, sedangkan pengguna media sosial di Indonesia pada Januari 2020 ada 160 juta pengguna meningkat menjadi 12 juta $( \pm 8,1 \%)$ antara April 2019 sampai dengan Januari 2020, penetrasi media sosial di Indonesia mencapai $59 \%$ pada Januari 2020. (Digital Indonesia; 2020). Bengkulu saat ini generasi millennial mencari identitas melalui media internet. Bagi generasi $\mathrm{Z}$ media internet efektif dan efisien untuk mencari jati diri. Di mana internet memberikan banyak kemudahan pada era millennials.

Sejak diumumkan pemerintah mengenai kasus pertama Corona virus Disease 2019 (Covid-19) pada bulan Maret 2020 yang lalu, Indonesia mengalami masa-masa sulit dimana bangsa ini dihadapkan pada masa pandemi yang tidak pernah diprediksi sebelumnya. Hampir seluruh sektor kehidupan bangsa terdampak dalam banyak sektor baik ekonomi, sosial, budaya, politik dan tidak terkecuali di sektor pendidikan. Covid-19 ini menyebar begitu cepat dan hampir ke semua negara, termasuk Indonesia, sehingga Badan Kesehatan Dunia (WHO) menjadikan wabah ini sebagai pandemi global pada tanggal 11 Maret 2020. Di sektor pendidikan, pemerintah melalui Kementerian Pendidikan dan Kebudayaan (Kemdikbud) telah menerapkan kebijakan learning from home terutama bagi satuan pendidikan yang berada di wilayah zona kuning, oranye dan merah. Hal ini merujuk pada Keputusan Bersama Menteri Pendidikan dan Kebudayaan, Menteri Agama, Menteri Kesehatan dan Menteri Dalam Negeri tentang Panduan Penyelenggaraan Pembelajaran pada Tahun Ajaran 2020/2021 dan Tahun Akademik 2020/2021 di masa Covid-19. Bagi satuan pendidikan yang berada di zona hijau, dapat melaksanakan pembelajaran tatap muka dengan tetap memperhatikan protokol kesehatan. Learning from home dilaksanakan dengan sistem Pembelajaran Jarak Jauh (PJJ). Dalam Undangundang No. 20 tahun 2003 pasal 1 ayat 15, dijelaskan bahwa PJJ adalah pendidikan yang peserta didiknya terpisah dari pendidik dan pembelajarannya menggunakan berbagai sumber belajar melalui teknologi komunikasi, informasi dan media lain. Dengan diterapkannya sistem pembelajaran daring, secara otomatis proses pembelajaran menjadi berubah secara signifikan, yang pada awalnya bersifat konvensional yang menggunakan alat bantu papan tulis, buku-buku, diktat, modul dan sumber belajar lainnya menjadi terisolirkan akibat pandemi saat ini sehingga berakibat pada budaya online berbasis pembelajaran yang dirasa masih sulit untuk diterima oleh dosen, mahasiswa, orang tua dan institusi pemerintah baik negeri maupun swasta.

Peneltian sebelumnya telah diteliti berbagai solusi pemecahan masalah pembelajaran daring di masa pandemi covid 19, yaitu meningkatkan kompetensi penguasaan IT, pengawasan intensif dengan melibatkan peran orangtua, dan memberikan penugasan secara manual (Asmuni:2020). Selanjutnya pengolahan media pembelajaran interaktif berbasis hypermedia dapat meningkatkan minat dan motivasi siswa dalam belajar, memudahkan mereka dalam memahami materi yang diberikan oleh guru (Hartanti:2019). Sedangkan sistem kelas virtual dan pengelolahan pembelajaran berbasis 3-Dimensional virtual world dapat memberikan kepuasaan dan mudah diterima oleh peserta didik (Rizal,dkk: 2018).

Dari uraian di atas, dipahami bahwa pembelajaran daring merupakan solusi alternatif pelaksanaan pembelajaran di masa pandemi covid-19, meskipun memunculkan sejumlah permasalahan dalam penerapannya baik bagi dosen, mahasiswa maupun institusi pendidikan. Maka berdasarkan masalah proses pembelajaran di masa pandemi covid 19 berbeda dari penelitian sebelumnya yaitu optimalisasi kelas virtual dalam proses pembelajaran berbasis google classroom dan hipnoterapi. Hasil penelitian ini diharapkan dapat menjadi bahan informasi dan rujukan dalam melaksanakan pembelajaran daring, baik bagi dosen, mahasiswa, perguruan tinggi, orang tua maupun pihak pemerintah.

\section{Metode Penelitian}

Metode yang digunakan dalam penelitian ini mengikuti teknik pengumpulan data yang meliputi kepustakaan, wawancara, proses pembuatan, implementasi dan evaluasi. Subjek penelitian adalah 37 mahasiswa $\mathrm{P}$ Kom Universitas Dehasen Bengkulu pada mata kuliah Kurikulum dan Teknoogi Kejuruan tahun ajaran 2020/2021 dengan rentang usia 18-22 tahun. 


\section{Hasil dan Pembahasan}

Hasil penelitian diperoleh melalui kepustakaan. Deskripsi hasil penelitian adalah sebagai berikut:

1. Kepustakaan

Kelas Virtual dapat berarti sekelompok siswa yang menghadapi pelajaran ataupun kuliah tertentu di perguruan tinggi, sekolah, maupun lembaga pendidikan sedangkan Maya menurut kamus Webster's bisa berarti simulasi, demo, bekerja secara electronik, bisa berpindah-pindah saat anda berada dimana saja, tidak benar- benar secara fisik. Sehingga kelas maya bisa di artikan secara harafiah adalah sekumpulan siswa yang menghadapi pelajaran tertentu secara tidak langsung (tidak tatap muka) secara elektronik dimana saja kapan saja. Dalam pengertian umum Kelas Maya adalah kelas yang diadakan tanpa tatap muka secara langsung antara pengajar dan yang menerima bahan ajar. Kelas virtual berhubungan langsung dengan internet. Dimana pengajar menyediakan sebuah forum kepada para penerima bahan ajar dan melakukan diskusi seperti kegiatan belajar mengajar dikelas.

Google classroom atau ruang kelas google merupakan suatu sarana media pembelajaran campuran untuk ruang lingkup pendidikan yang dapat memudahkan pengajar dalam membuat, membagikan dan menggolongkan setiap penugasan tanpa kertas (paperless). Software tersebut telah diperkenalkan sebagai keistimewaan dari Google Apps for Education yang rilis pada tanggal 12 Agustus 2014 (Corbyn, 2019: 13). Menurut website resmi dari Google, aplikasi Google Classroom merupakan alat produktivitas gratis meliputi email, dokumen dan penyimpanan. classroom di desain untuk memudahkan guru (pengajar) dalam menghemat waktu, mengelola kelas dan meningkatkan komunikasi dengan siswa-siswanya. Dengan google classroom ini dapat memudahkan peserta didik dan pengajar untuk saling terhubung di dalam dan di luar sekolah (Class, 2018: 16). Rosemarie De Loro, seorang guru asal New York, menyatakan selama 60 tahun dia mengajar tidak pernah sekalipun menggunakan komputer. Namun, sejak memiliki chromebook dan google classroom di dalamnya, dia bisa dengan mudah memberikan pekerjaan rumah digital kepada murid-muridnya dan memberikan tanggapan secara langsung, kapan pun dan di manapun (Biantoro, 2014: 23). Google classroom didesain untuk empat pengguna yaitu pengajar, siswa, wali dan administrator. Bagi pengajar dapat mengelola kelas, tugas, nilai serta memberikan masukan secara langsung (real-time). Siswa dapat memantau materi dan tugas kelas, berbagi materi dan berinteraksi dalam aliran kelas atau melalui email, mengirim tugas dan mendapat masukan dan nilai secara langsung. Administrator dapat membuat, melihat atau menghapus kelas di domainnya, menambahkan atau menghapus siswa dan pengajar dari kelas serta melihat tugas di semua kelas di domainnya (Graham \& Borgen, 2018: 77).

Manfaat Google Classroom Menurut Brock (2015: 25) Google classroom ini memberikan beberapa manfaat seperti: 1) kelas dapat disiapkan dengan mudah, pengajar dapat menyiapkan kelas dan mengundang siswa serta asisten pengajar. Kemudian di dalam aliran kelas, mereka dapat berbagi informasi seperti tugas, pengumuman dan pertanyaan. 2) menghemat waktu dan kertas, pengajar dapat membuat kelas, memberikan tugas, berkomunikasi dan melakuan pengelolaan, semuanya di satu tempat. 3) pengelolaan yang lebih baik dalam hal ini siswa dapat melihat tugas di halaman tugas, di aliran kelas maupun di kalender kelas. Semua materi otomatis tersimpan dalam folder Google Drive. 4) penyempurnaan komunikasi dan masukan, pengajar dapat membuat tugas, mengirim pengumuman dan memulai diskusi kelas secara langsung. Siswa dapat berbagi materi antara satu sama lain dan berinteraksi dalam aliran kelas melalui email. Pengajar juga dapat melihat dengan cepat siapa saja yang sudah dan belum menyelesaikan tugas, serta langsung memberikan nilai dan masukan real-time. 5) dapat digunakan dengan aplikasi yang anda gunakan, kelas berfungsi dengan Google Document, Calender, Gmail, Drive dan Formulir. 6) aman dan terjangkau, kelas disediakan secara gratis. Kelas tidak berisi iklan dan tidak pernah menggunakan konten atau data siswa untuk tujuan iklan.

Wolman mendefinisikan Hipnoterapi sebagai sebuah metode untuk mengubah perilaku melalui sugesti dan tanpa alat. Melibatkan teoriteori psikologi ke dalam terapi tersebut. Hipnoterapi merupakan proses yang dinamis dan berpusat pada klien itu sendiri (Wulandari, 2016 : 5). Hipnoterapi adalah salah satu jenis terapi pikiran yang menggunakan teknik hipnosis untuk menyembuhkan penyakit psikis maupun fisik. Secara umum, Hipnoterapi sangat berkaitan dengan aktivitas kerja otak manusia. Aktivitas ini sangat beragam pada setiap kondisi yang sesuai dengan gelombang otak manusia (Sugiarso, 2013 
: 2). Hipnoterapi merupakan sebuah teknik pengobatan yang menggunakan alam bawah sadar manusia yang secara umum berkaitan dengan aktivitas kerja otak manusia untuk memberikan efek psikis dan fokus terhadap pembelajaran melalui online system di masa pandemi covid-19 saat ini.

\section{Proses Pembuatan}

Google Classroom sebagai alternatif pembelajaran Pada tahap awal di masa pandemi covid-19 di tahun 2020. Pengembangan google classroom dapat diakses oleh seluruh orang dengan menggunakan google pribadi. Hal ini yang dapat dimanfaatkan oleh guru, siswa dan wali murid dalam pembelajaran, sehingga tercapainya kompetensi yang diharapkan di dalam kurikulum pembelajaran.

Adapun proses pembuatannya dapat dijelaskan sebagai berikut, antara lain:

a. Masuk ke akun Google classroom

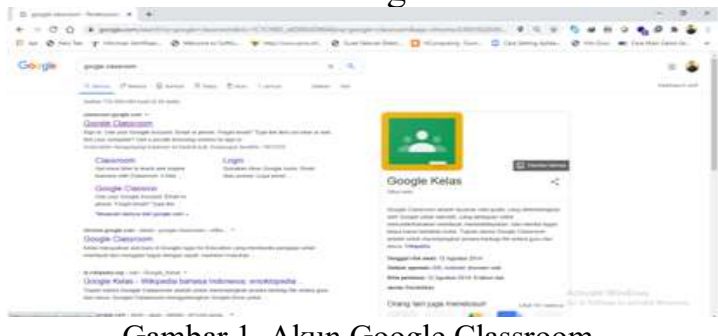

Gambar 1. Akun Google Classroom

b. Membuat classroom dengan mengklik tombol tambah di sisi kanan atas.

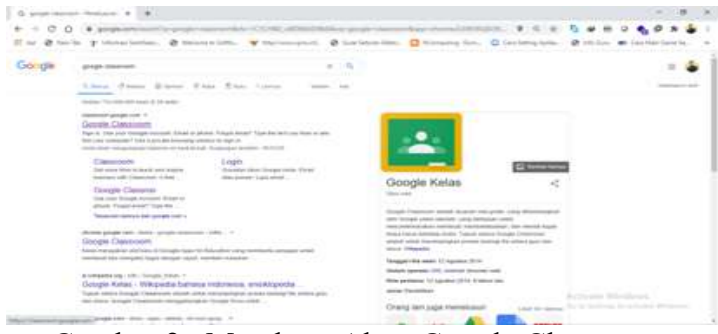

Gambar 2. Membuat Akun Google Classroom

c. Membuat nama mata kuliah, mengisi form create class, dilanjutkkan dengan mengcrate nama mata kuliah.

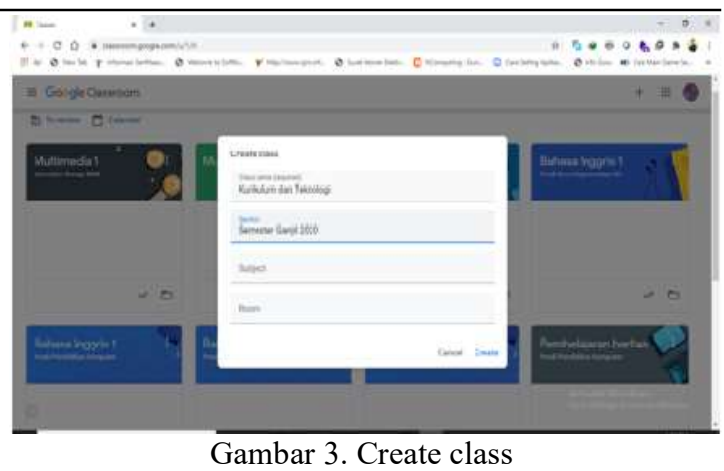

d. Classroom sudah selesai dibuat, kemudian sudah mendapatkan class code yang bisa langsung dibagikan kepada mahasiswa.

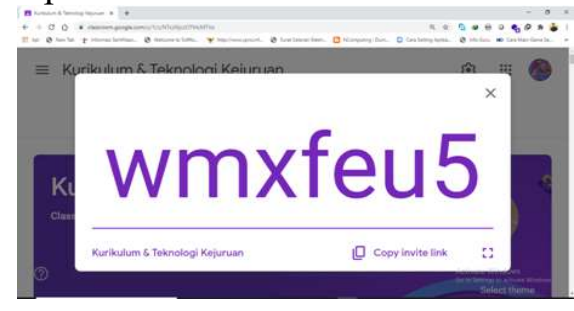

e. Classroom siap untuk diisi dengan konten materi perkuliahan.

3. Implementasi

Fitur - Fitur Google Classroom Penelitian yang dilakukan oleh Shampa Iftakhar (2016: 45) dengan judul Google Classroom: What Works and How? berisi mengenai bahwa google classroom membantu untuk memonitoring mahasiswa untuk belajar. Dosen dapat melihat seluruh aktivitas mahasiswa selama pembelajaran di google classroom. Interaksi antara dosen dan mahasiswa terekam dengan baik.

Adapun tahap implemenatasi interaksi antara dosen dan mahasiswa terlihat pada uraian sebagai berikut;

a. Cara mengisi konten dengan materi PPT, Docx, PDF, dll

Klik "Stream", tulis salam pembuka dan mensugesti alam bawah sadar mereka untuk tetap optimis dan berfikir positif dalam menghadapi pandemi covid-19 dimana setiap orang diberikan kemampuan untuk memahami anjuran yang diberikan pemerintah daerah.

- instruksi materi untuk siswa Klik "Add"untuk melampirkan file.

- Pilih "File" 
- Setelah file ditambahkan klik "Post"

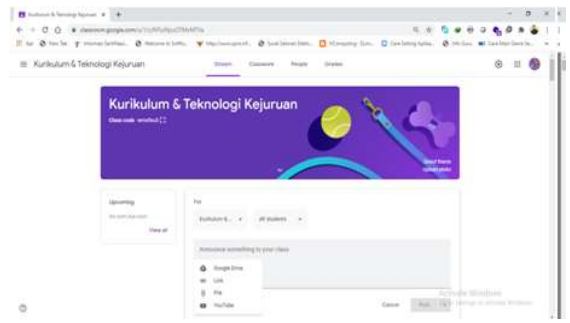

Gambar 5. Mata kuliah Kurikulum dan Teknologi

b. Cara yang sama dengan No.6 dapat dilakukan untuk mengisi konten dengan materi menggunakan google drive, link dan youtube

- Klik "Stream", tulis salam pembuka dan instruksi materi untuk siswa

- Klik "Add" untuk melampirkan file

- Pilih "google drive"atau "link" atau "youtube"

- Setelah file/link ditambahkan klik "Post".

c. Mengisi tugas untuk siswa

- Klik "Classwork"

- Klik "+Create

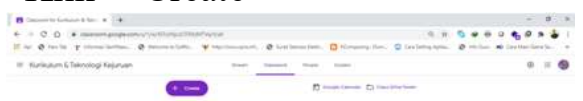

Gambar 6. Classwork

d. Tugas di buat berupa Tugas Mandiri Berkelompok terstruktur yang mana waktu pengumpulan nya kita batasi.

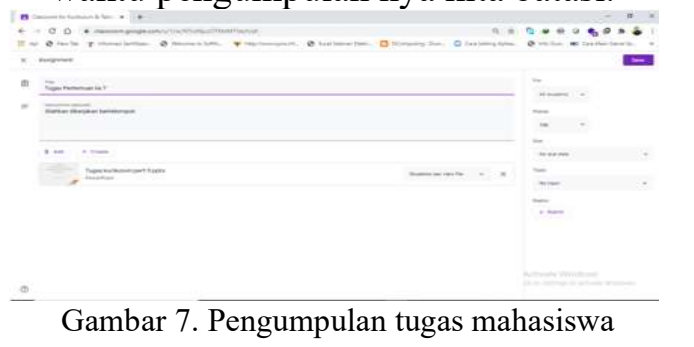

e. Hasil upload pekerjaan mahasiswa.

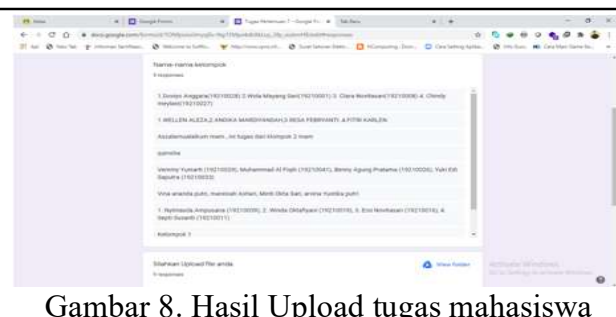

Gambar 8. Hasil Upload tugas mahasiswa

f. Ujian juga dilakukan secara daring menggunakan google classroom dan aplikasi Zoom Meeting.

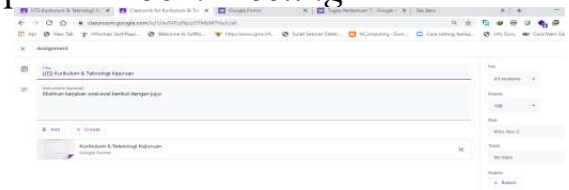

Gambar 9. Ujian secara daring

g. Hasil pekerjaan mahasiswa

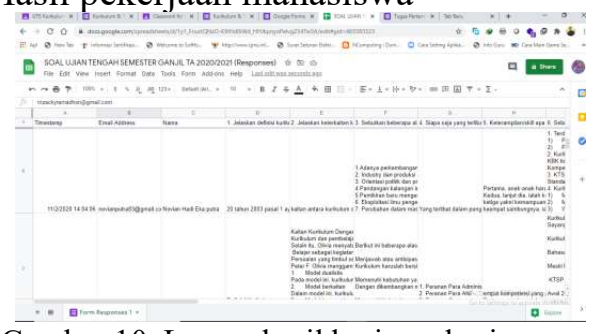

Gambar 10. Laman hasil kerja mahasiswa

Peneliti dapat simpulkan bahwa proses pembelajaran menggunakan sistem virtual class berbasis google classrom dan hipnoterapi dapat menunjang proses pembelajaran dan meningkatkan konsentrasi mahasiswa melalui daring di masa pandemi covid-19 di tahun 2020.

4. Evaluasi

Berdasarkan hasil implementasi penelitian, dari 37 orang mahasiswa ada 27 orang mahasiswa yang mengerjakan tugas maupun soal ujian tepat waktu berdasarkan waktu yang telah disepakati bersama sebelum ujian di mulai dengan persentase $73 \%$. Sedangkan 10 orang belum mampu tepat waktu dalam mengerjakan soal ujian yang telah diberikan dengan persentase $27 \%$. Adapun penyebabnya beradasarkan wawancara adalah keterbatasan jaringan. Sejalan dengan pernyataan Brock (2015: 25) tentang manfaat google classroom, yaitu dapat mempersiapkan kelas tepat waktu, menghemat kertas dan alat tulis yang lain,pengelolaan tugas dan ujian lebih tersistematis,penyempurnaan komunikasi secara aktif antara dosen dan 
mahasiswa dalam berdiskusi dan memberikan komentar kepada mahasiswa tentang pembahasan, dapat digunakan dengan aplikasi yang digunakan, kelas berfungsi dengan Google Document, Calender, Gmail, Drive dan Formulir. dan aman serta terjangkau, kelas disediakan secara gratis.

\section{Kesimpulan}

Berdasarkan hasil penelitian dan pembahasan, disimpulkan bahwa optimalisasi sistem virtual class mampu memberikan manfaat dalam pemanfaatan google classroom bagi dosen dan mahasiswa di masa pandemi covid-19 dengan memberikan tugas, skema penilaian, komunikasi yang aktif dalam membahas materi, efisiensi waktu dalam proses pembalajaran berlangsung. Sejalan dengan proses pembelajaran mahasiswa diberikan sugesti di dalam alam bawah sadar mereka untuk tetap fokus dan konsentarasi terhadap materi perkuliahan dan dapat memanajemen pola pikir dan tindakan mereka yang sesuai dengan harapan dosen dan orang tua.

\section{Daftar Pustaka}

Abdul Majid \& Chaerul Rochman. 2015. Pendekatan Ilmiah Dalam Implementasi Kurikulum 2013. Bandung Remaja Rosdakarya

Aditya. 2013. Data dan Metode Pengumpulan Data Penelitian. Surakarta: Poltekkes Kemenkes Surakarta.
J.Moleong, Lexy. 2014. Metode Penelitian Kualitatif, Edisi Revisi. bandung: PT Remaja Rosdakarya.

Rusman. 2013. Belajar dan Pembelajaran Berbasis Komputer. Bandung: Alfabeta

Sudjana, Nana. 2005. Dasar-dasar Proses Belajar Mengajar. Bandung. Sinar Baru Algensindo.

Sugiyono. 2018. Metode Penelitian Pendidikan Pendekatan Kuantitatif, Kualitaif, dan R\&D. Bandung: Alfabeta.

Suharsimi, Arikunto. 2010. Preosedur Penelitian Suatu Pendekatan Praktik.Jakarta: Rineka Cipta.

Suryani, Nunuk dan Leo Agung. 2012. Strategi Belajar Mengajar. Yogyakarta: Ombak.

Sutikno, Sobry. 2014. Metode \& Model-Model PPembelajaran Menjadikan Proses Pembelajaran Lebih Variatif, Aktif, Inovatif, Efektif, dan Menyenangkan LLombok: Holistica.

Syatra Yusvavera Nuni. 2013. Desain Relasi Efektif Guru dan Murid. Jogjakarta : Buku biru.

Usman. 2006. MetodePenelitian Sosial. Bumi Aksara. Jakarta.

Wulandari, Ayu.2016. Pengaruh hipnoterapi terhadap frekuensi merokok pada remaja. http://eprints.unm.ac.id/4064/1. 